\section{Small countries are unexpected winners in ERC grant tables}

SIR - Your Editorial 'Supporting the future' (Nature 453, 958; 2008) and News Feature 'The research revolution' (Nature 453, 975-976; 2008) rightly point out that the European Research Council (ERC) will change the future of European science funding for the better. But the conclusion that most of the ERC's young-investigator research grants go to the top three of European research - the United Kingdom, France and Germany - disguises a less impressive performance by these countries when the numbers of research grants awarded are considered relative to the overall population or gross domestic product (GDP) (see table).

It seems that the countries where the greatest number of grants are obtained per capita - and hence with the most efficient young scientists - are Cyprus, Israel, Switzerland and the Netherlands. Bulgaria, which won just one grant, does better than the traditional strongholds in terms of grants in relation to GDP, and Hungary with six is in third position.

Germany, along with Portugal, Norway and the Czech Republic, does poorly, trailing Italy and Greece in grants per GDP. This might be partly because Germany doles out plenty of its own young-investigator grants, which are worth as much as the highly competitive ERC grants. Young German researchers, unlike their Italian counterparts, for example, might therefore not feel so desperate to pursue European money.

What other surprises may come to light, after further analysis and contextualization of the useful numbers provided by this first competition for ERC young-investigator grants?

Friedrich Frischknecht Department of Parasitology, University of Heidelberg Medical School, INF 324, 69120 Heidelberg, Germany e-mail: freddy.frischknecht@med. uni-heidelberg.de

\begin{tabular}{|c|c|c|c|c|c|c|}
\hline \multicolumn{7}{|c|}{ Analysis of ERC grant awards by country } \\
\hline Country & Grants* & $\begin{array}{l}\text { Population } \\
\text { (millions) } \dagger\end{array}$ & $\begin{array}{c}\text { GDP } \\
(U S \$ b n) \dagger\end{array}$ & $\begin{array}{c}\text { GDP per } \\
\text { capita (US\$) }\end{array}$ & $\begin{array}{l}\text { Ranking, } \\
\text { grants per } \\
\text { capita }\end{array}$ & $\begin{array}{l}\text { Ranking, } \\
\text { grants per } \\
\text { overall GDP }\end{array}$ \\
\hline UK & 58 & 59.7 & 2,199 & 36,830 & 7 & 10 \\
\hline France & 39 & 60.5 & 2,127 & 35,150 & 9 & 12 \\
\hline Germany & 33 & 82.7 & 2,795 & 33,800 & 16 & 16 \\
\hline Netherlands & 26 & 16.3 & 624 & 38,290 & 4 & 5 \\
\hline Italy & 26 & 58.1 & 1,763 & 30,340 & 15 & 14 \\
\hline Israel & 24 & 6.7 & 123 & 18,420 & 1 & 1 \\
\hline Spain & 24 & 43.1 & 1,125 & 26,090 & 11 & 11 \\
\hline Switzerland & 16 & 7.3 & 367 & 50,280 & 3 & 4 \\
\hline Sweden & 11 & 9 & 358 & 39,740 & 6 & 8 \\
\hline Belgium & 10 & 10.4 & 371 & 35,660 & 8 & 9 \\
\hline Finland & 7 & 5.2 & 193 & 37,000 & 5 & 7 \\
\hline Hungary & 6 & 10.1 & 109 & 10,820 & 10 & 3 \\
\hline Greece & 4 & 11.1 & 225 & 20,290 & 17 & 13 \\
\hline Austria & 4 & 8.2 & 306 & 37,330 & 13 & 15 \\
\hline Denmark & 3 & 5.4 & 259 & 47,910 & 12 & 17 \\
\hline Cyprus & 2 & 0.7 & 33 & 46,870 & 2 & 2 \\
\hline Ireland & 2 & 4.1 & 202 & 49,220 & 14 & 19 \\
\hline Portugal & 2 & 10.5 & 183 & 17,460 & 19 & 18 \\
\hline Norway & 1 & 4.6 & 296 & 64,240 & 18 & 21 \\
\hline Bulgaria & 1 & 7.7 & 26.6 & 3,460 & 20 & 6 \\
\hline Czech Rep. & 1 & 10.2 & 124 & 12,190 & 21 & 20 \\
\hline
\end{tabular}

\section{Human microbiome: hype or false modesty?}

SIR - Your Editorial 'Who are we?' (Nature 453, 563; 2008) warns that research into the human microbiome should not be oversold until medical promise is established. Fads, hype and false promises have no place in any research, but neither should we bias debate by suppressing reasonable extrapolation.

We were led to believe, wrongly, that genome sequences would open our eyes and we would understand - but that did not reduce the value of those sequences in the slightest.

They are more valuable than expected precisely because we did not understand them as expected. Research showing us that we do not comprehend what seems to be obvious can be important. Unfortunately, it is the most difficult to conceive, justify, fund and publish because, until we do, we think its premises are wrong.

Decisions on whether to fund particular projects are not scientific decisions. They are social decisions, and may therefore be over-influenced by hype. Research funding must compete with other funding needs, and research hype is up against the hype of military spending, spiralling oil costs and the latest celebrity exploits. Waiting for medical benefits to be proven before funding basic research would mean that basic research would never be funded.

Medicine is founded on germ theory, physiology, hygiene and antibiotics. Yet there are profound gaps in our understanding of those interactions. Health conditions common in the developed world (obesity, diabetes, allergies, asthma, heart, vascular and inflammatory diseases) remain rare to nonexistent in the rural undeveloped world, despite the lack of potential treatment. The 'hygiene hypothesis' tries to explain these differences, but so far no protective agent has been found. If the microbiome project can eventually deliver such an agent, or agents, and stop even a fraction of the health decline associated with economic development, the effects will still be profound.

The analogy of the microbiome with rainforest biodiversity is apt. We should exhaustively sample and understand the diversity of both in the wild before the 'clear cutting' of modern agriculture and hygiene practices irreversibly destroys them both.

David R. Whitlock Nitroceutic LLC, Watertown, Massachusetts 02472, USA

e-mail: daedalus4u@yahoo.com Competing financial interests: D. R. W. has patented the use of autotrophic ammonia-oxidizing bacteria as a topical treatment.

\section{Human microbiome: take-home lesson on growth promoters?}

SIR - Your News Feature 'The inside story' (Nature 453, 578580; 2008) highlights the potential importance of the gut microbiome in understanding health. As you discuss, human profiles differ in obese and lean individuals and are being scrutinized for their possible influence on weight.

A factor you don't mention is the routine administration over some 50 years of antibiotics and probiotics as growth promoters to farm animals. Use of antibiotics for this purpose was banned in 2005 in the European Union, but it continues in many places (including the United States).

Compounds with antibiotic activity and bacteria with probiotic activity have been widely tested as growth promoters (see, for example, M. Khan et al. Brit. Poultry Sci. 48, 732-735; 2007). The probiotics used in agricultural industries are mainly Lactobacillus 